\title{
Analysis of mechanical equipment failure at the hard coal mine processing plant
}

\author{
Jacek SITKO ${ }^{* 1}$ and Zakirhussain FARHAD ${ }^{2}$
}

Authors' affiliations and addresses: ${ }^{1}$ Silesian University of Technology, Faculty of Organization and Management, Roosevelt str. 26, 41-800 Zabrze, Poland

e-mail: jacek.sitko@polsl.pl

${ }^{2}$ University of Kabul Polytechnic, Faculty of electromechanic, Department of Power engineering, Afghanistan

e-mail: zakirhussainfar@kpu.edu.af

\section{*Correspondence:}

Jacek Sitko, Silesian University of Technology, Faculty of Organization and Management, Roosevelt str. 26, 41-800 Zabrze, Poland tel.: +48781404739

e-mail: jacek.sitko@polsl.pl

How to cite this article:

Sitko, J. and Farhad, Z. (2020). Analysis of mechanical equipment failure at the hard coal mine processing plant. Acta Montanistica Slovaca, Volume 25 (3), 350-360

DOI:

https://doi.org/10.46544/AMS.v25i3.8

\begin{abstract}
The paper presents an analysis of mechanical equipment failures in the mechanical treatment plant of a hard coal mine using the ParetoLorenz diagram. Then, changes were proposed to reduce the failure rate and the possibility of earlier detection of malfunctioning machines.A detailed analysis of the processenrichment of coarse assortments on a grain washer is presented.

One of the quality management tools - the Pareto-Lorenz diagram was used to analyze the equipment failure rate during the thick product enrichment process.

It is important to assess the mechanical failure of equipment and to show which machines cause the most problems.

The research found the devices most influencing the elements of theprocesses causing the failures. These include heavy liquidconcentrator and screens.

Based on the information provided by the mine, such as repair, inspection and maintenance sheets, equipment records an evaluation of the most frequent mechanical failures during the operation of equipment in the process of thicker products enrichment was conducted. An attempt was made to assess

the failure rate of equipment on a grain washer. Then, changes were proposed to reduce the failure rate and improve their detectability.
\end{abstract}

\section{Keyword}

hard coal mine, operation, failure, analysis, repair 


\section{Introduction}

Hard coal is extracted to the surface in the form of various sizes of coal grains and waste rock: stone, sand, slate (Biały, 2013; Biały, 2014; Biały et al., 2018). In order to be a valuable commercial product, it must be adapted to the user's needs. Such adaptation occurs in processing plants and consists of removing useless components (mineral substance) of the excavated material. The extracted coal is subjected to enrichment processes. The mineral substance is undesirable in the technology of using coal. It lowers the quality of raw material. Consequently, the quality of product causes corrosion of machines and increases transport costs. To a large extent, the excavated steam coal meets the guarantee parameters of boilers and does not require enrichment. Enriched steam coal is characterized by higher calorific value and lower emission of sulphur oxides (Fuerstenau et al., 2007; Lutyński \& Osoba, 2009).

The main task of mechanical processing is the enrichment of useful minerals, which consists in separating from the raw material, excavated in a deep mine, the possibly pure useful grains, possible adhesions of the useful mineral with waste rock, and the possibly pure grains of waste without a useful component. The enrichment process should be technologically developed and then technically solved in such a way as to obtain in concentrate the maximum amount of valuable, useful mineral grains with the least possible waste losses.

In order to obtain optimum enrichment results, the raw material is thoroughly tested beforehand to determine its mineralogical characteristics, physical and technological properties, such as densimetric composition, susceptibility to gravitational enrichment, electrical and magnetic enrichment, susceptibility to flotation enrichment, ease or difficulty of enrichment, degree of concentration of useful grains, etc. (Saga et al., 2020; Vaclav et al., 2017). Based on these tests, a full technology is developed, determining which subsequent technological processes should be applied in order to obtain optimum results in raw material enrichment.

The technology developed for enrichment of useful minerals should take into account the full technological requirements of further processing or direct use of the separated concentrates, eliminating the need for additional processing operations or the use of costly additional treatment methods in the processing technology, if their elimination is possible by appropriate selection of raw mineral enrichment technology. Technological processes should be selected and applied in such a way that even the smallest amount of raw mineral is not diverted for further use, even if it could be used in this form as a low-value raw material with economic losses of another branch of the national economy or causing damage to the natural human environment. For example, combustion of unenriched fuels with high ash and sulphur content causes very large losses in the energy economy and enormous pollution of the natural human environment. The process of raw material enrichment is preceded by preparatory processes, such as: screening the material into grain classes established by the technological design, crushing, rinsing, hydraulic or aerodynamic classification, etc. Preparation operations aim to bring the raw material to such a state that the enrichment process achieves a maximum concentration of useful grains. In most cases, simple technological characteristics of useful raw minerals are sufficient to prepare them once for the enrichment process, obtaining the optimum effect of their enrichment. In the case of complex mineral characteristics, a single preparation for enrichment is usually insufficient, as only a part of the useful minerals are obtained, and the rest of useful minerals remain in the form of adhesions with waste rock. In such cases, a series of intermediate products must be separated in turn, prepared (by crushing and screening), and then enriched again until the maximum assumed degree of extraction of the mineral's useful grains is reached. Repeated preparation of raw material and subsequent enrichment mainly concerns minerals occurring in the form of injections of useful grains - of varying grain sizes - into the waste rock and into multimetallic ores, from which each useful component must be separated separately.

The processing technology uses the physical and physicochemical properties of the useful minerals and wasterockgrains, differentiating them from each other and enabling their separation.The problem of producing pure coal is quite a complex one. On the one hand, these are technical possibilities of coal enrichment. On the other hand, these are the needs of coal users, who set conditions as to its quality in their contracts. Coal for energy purposes directed to the domestic market is significantly diversified in terms of quality. It depends primarily on the extent of mechanical enrichment of this coal. A large part of the coal sold is not enriched, especially in those cases where the quality parameters of raw coal meet the users' needs (Blaschke \& Nycz, 2003; Blaschke \& Nycz, 2007; Bozek \& Turygin, 2014).

\section{Overview of the coal processing}

In the Mechanical Coal Processing Plant, the nominal capacity of which is $750 \mathrm{Mg}$ per hour, coal in class $120 \div$ $16 \mathrm{~mm}$ in a heavy liquid is enriched, while the raw coal after separation of grain class $4(6) \div 0 \mathrm{~mm}$ is enriched in jiggers. The processing plant is supplied with thermal coal.The excavated material is directed to WK1 vibration sifter with $120 \mathrm{~mm}$ holes. After passing through the screening belt, the upper product of screen is crushed in the KWK-100UM crusher for granulation below $120 \mathrm{~mm}$. Whereas the bottom product of screen and 
the crushed grain class $+120 \mathrm{~mm}$ are combined and collected in two raw coal tanks (A and B) with a total capacity of $3600 \mathrm{Mg}$ (A $800 \mathrm{Mg}$ and B $2600 \mathrm{Mg}$ ).

The coal is fed to the initial classification node, equipped with a PZ 3090 screen with 16 mm holes from tanks. The plant has a possibility of pre-separation of the raw coal dust stored in a tank with a capacity of 800 $\mathrm{Mg}$.

For this purpose, there are two screens, which are probably built in PWP $1-2 \times 4.5$ equipped with seams with holes of $16 / 20$ and $16 \mathrm{~mm}$ respectively. The upper product is directed to the initial classification node from the last screen, while the lower products of both screens can already be directed alternatively, for loading into carriages, on the dike or to a heat and power plant. The upper product of PZ 3090 screen, i.e. grain class +16 $\mathrm{mm}$, is enriched in a two-product heavy liquid enricher, type Drewboy 3.2. The enrichment is carried out in a suspension enrichment in a heavy liquid with a specific gravity of $1.6 \mathrm{~g} / \mathrm{cm}^{3}$. The resulting carbon concentrate is dehydrated on a solid sieve, and vibration screen PWP1 with $1 \mathrm{~mm}$ slotted sieves (Blaschke, 1984; Blaschke, 2009). Drainage from the solid sieve and the first part of PWP1 screen is directed to a tank of working fluid for re-use in the enrichment process, while the drain from the second part of the screen, which is mainly the result of using showers - part of the suspension after recuperation and water from clean water tanks are treated as a product for regeneration (Brodny \& Tutak, 2018; Brodny \& Tutak, 2019). By means of a conveyor system, the dehydrated concentrate is directed to a fixed grate with $30 \mathrm{~mm}$ holes. Grain class $+30 \mathrm{~mm}$ is fed to PWP1 $1.5 \times$ 3.75 screen with 40 and $80 \mathrm{~mm}$ holes. The upper product (cube) is collected in tanks, and the lower products of the screen are classified on two $1.8 \times 5.25$ PWP1 $1.8 \times 5.25$ screens with the following holes: the first $20 \mathrm{~mm}$ and the second 25 and $31 \mathrm{~mm}$, respectively. Grain classes separated in this way are already commercial products and are directed to appropriate tanks. The lower product, which has been separated on a solid grate, is directed to WE vibration screens, deposits of which are equipped with screens with 8, 25 and $30 \mathrm{~mm}$ holes. Separated grain classes are commercial products that are components of commercial products and directed to suitable tanks.

Class $>30 \mathrm{~mm}$ is crushed by means of KD twin-roller crusher and returned to the screens again via B-300 bucket elevator (Baranov et al. 2017; Brodny, 2012).

The described node is used to increase the classification efficiency of medium grades of enriched coal into individual commercial classes and to eliminate the upper class, i.e. grains above $30 \mathrm{~mm}$.

Coarse-grained waste from the enrichment unit is collected by means of a chute and fed to PWP1 $2.2 \times 4.5$ screen with $1 \mathrm{~mm}$ slotted sieves. After dehydration, the waste is collected in stone tanks on the wash. Drainage from the first part of PWP1 screener is directed to a tank of working fluid for re-use in the enrichment process, while the drain from the second part of the screener, resulting mainly from the use of sprays, is treated as a product for regeneration (Akatov et al., 2019).

The bottom product of PZ 3090 screener, which is a raw product with granulation of $16 \div 0 \mathrm{~mm}$, is directed to LIWELL LF - $3.0 \times 8.82$ screeners with 4 (6) mm holes. On the PWP 1 screener with a slot of $0.75 / 0.5 \mathrm{~mm}$, the coal concentrate is initially dewatered, and finally on centrifuges: WOW-1.3 and NAEL-3A, which are equipped with sieve baskets with $0.35 \mathrm{~mm}$ holes. The obtained intermediate product is dehydrated on a bucket elevator. It is characterized by high ash content, thus it is directed to waste; if necessary, it can also be directed to a feeder and re-enrichment. The coal waste is dehydrated on the bucket elevator. Concentrated coal is directed to heaps or to raw coal.

The final production of the processing plant consists of:

a) concentrated products:

- coarse-grained concentrate,

- coal concentrate,

- concentric coal,

- raw coal $16(20) \div 0 \mathrm{~mm}$,

- raw coal $4(6) \div 0 \mathrm{~mm}$,

b) waste:

- coarse-grained waste,

- coal waste,

- coal waste (from filter presses).

The plant has tanks for commercial products with a total capacity of about $1200 \mathrm{Mg}$ located

at the loading points and tanks with a capacity of about $400 \mathrm{Mg}$ at the point of general cargo sales. Commercial products' basic sale is carried out by loading them on railcars and cars, in the point of sale of general cargo - by road transport. There is also a possibility of directing particular coarse-grained products, raw material and commercial products to heaps and then loading them on the cars or into railcars. The capacity of coal heaps is at the level of $90000 \mathrm{Mg}$.

Commercial products produced by the mine: 
- nut coke,

- pea coke,

- pea coke II,

- breeze coke M I,

- energy mixes M II .

Coarse-grained and coal waste is directed to three tanks with a total capacity of $300 \mathrm{Mg}$, and then transported by car or railcars to an external waste heap. Immediately after dehydration, sludge waste from filter presses is transported by road to this heap.

\section{Analysis of the failure rate of hard coal processing equipment}

The equipment used in the above process is subject to continuous production operations. They are subject to cyclical wear and increased failure rate. The most common cause of unexpected production interruptions is machine failure (Biały, 2017; Biały \& Fries, 2019; Biały, 2019; Brodny \& Szurgacz, 2017).

The Pareto-Lorenz diagram was used to analyze the failure rate of grain scrubbers during the enrichment process of thick products. In this case, it is important to assess the mechanical failure of equipment and show which machines generate the most failures.

The analysis stages were conducted using the Pareto-Lorenz diagram:

1. Collection of data on repairs of grain scrubbers devices (maintenance, overhaul and repair sheet).

2. Ranking the data by assigning individual repairs to specific devices.

3. Calculation of cumulative percentages for individual failures.

4. Preparation of Pareto-Lorenz diagram.

5. Interpretation of prepared diagram.

Total of all failures on particular units has been summarized in Table 1.

Table 1. Total equipment repairs

\begin{tabular}{|c|c|c|}
\hline $\begin{array}{c}\text { Equipment } \\
\text { number }\end{array}$ & Table 1. Total equipment repairs & Total repairs \\
\hline 1 & Trapezoidal feeder WPT 3.02 & 12 \\
\hline 2 & Screening machine PZ 3090 & 21 \\
\hline 3 & Belt conveyor B-1040 & 16 \\
\hline 4 & Screening machine PWP1 2.2 4.5 & 27 \\
\hline 5 & Heavy liquid enrichment DREWBOY & 22 \\
\hline 6 & Screening machine PWP1 3 $\times 5.25$ & 4 \\
\hline 7 & Belt conveyor B-1000 & 11 \\
\hline 8 & Belt conveyor B-1010 & 10 \\
\hline 9 & Pomp OŁ 150 & 1 \\
\hline 10 & Pomp OŁ 80 & 2 \\
\hline 11 & Recuperator reserve & 2 \\
\hline 12 & Recuperator & 1 \\
\hline 13 & Pomp OŁ 150 & 12 \\
\hline 14 & Hydrocyklon Krebs D-15 & 13 \\
\hline 15 & Mill MK 900 $\times 900$ & 6 \\
\hline 16 & Screening machine PWP 1K 1.5 x 3.75 & 5 \\
\hline 17 & Screening machine PWP 1K 1.8 $\times 5.5$ & 3 \\
\hline 18 & Screening machine PWP 1K 1.8 $\times 5.5$ & 4 \\
\hline 19 & Belt conveyor B-800 & 7 \\
\hline 20 & Belt conveyor B-630 & \\
\hline 21 & Belt conveyor B-1030 & \\
\hline 22 & Belt conveyor B-1020 & \\
\hline & & \\
\hline
\end{tabular}


The next step was to calculate the cumulative repair percentages, Table 2.

Table 2. Cumulative percentages for equipment repairs

\begin{tabular}{|c|c|c|c|}
\hline $\begin{array}{c}\text { Equipment } \\
\text { number }\end{array}$ & Equipment type & Number of repairs & Percentage rate \\
\hline 5 & Heavy liquid enrichment DREWBOY 3.2 & 27 & $14.1 \%$ \\
\hline 6 & Screening machine PWP1 3 5.25 & 22 & $11.5 \%$ \\
\hline 2 & Screening machine PZ 3090 & 21 & $10.9 \%$ \\
\hline 4 & Screening machine PWP1 2.2 4.5 & 16 & $8.3 \%$ \\
\hline 17 & Screening machine PWP 1K 1.8 55.5 & 13 & $6.8 \%$ \\
\hline 1 & Belt conveyor WPT 3.02 & 12 & $6.3 \%$ \\
\hline 16 & Screening machine PWP 1K 1.5 $\times 3.75$ & 12 & $6.3 \%$ \\
\hline 9 & Pomp OŁ 150 & 11 & $5.7 \%$ \\
\hline 10 & Pomp OŁ 80 & 10 & $5.2 \%$ \\
\hline 12 & Recuperator & 7 & $3.6 \%$ \\
\hline 22 & Belt conveyor B-1040 & 7 & $3.6 \%$ \\
\hline 18 & Screening machine PWP 1K 1.8 5.5 & 6 & $3.1 \%$ \\
\hline 19 & Belt conveyor B-800 & 5 & $2.6 \%$ \\
\hline 7 & Belt conveyor B-1000 & 4 & $2.2 \%$ \\
\hline 8 & Belt conveyor B-1010 & 4 & $2.1 \%$ \\
\hline 21 & Belt conveyor B-1020 & 4 & $2.1 \%$ \\
\hline 20 & Belt conveyor B-630 & 3 & $1.6 \%$ \\
\hline 3 & Belt conveyor B-1030 & 2 & $1.0 \%$ \\
\hline 13 & Pomp OŁ 150 & 2 & $1.0 \%$ \\
\hline 14 & Hydrocyklon Krebs D-15 & $1.0 \%$ \\
\hline 11 & Recuperator reserve & $0.5 \%$ \\
\hline 15 & Mill 900x900 & 1 & $0.5 \%$ \\
\hline
\end{tabular}

The analysis of the Pareto-Lorenzo diagram (Fig. 1) shows that the highest number of repairs - $78.6 \%$ is generated by 9 machines:

1. Heavy Liquids Enrichment TREWBOY 3.2

2. Screener PWP1 $3 \times 5.25$

3. Screener PZ 3090

4. Screener PWP1 $2.2 \times 4.5$

5. Screener PWP $1 \mathrm{~K} 1,8 \times 5,5$

6. Trapezoidal power supply WPT 3.02

7. Screener PWP $1 \mathrm{~K} 1.5 \times 3.75$

8. Pump OŁ 150

9. Pump OŁ 80. 


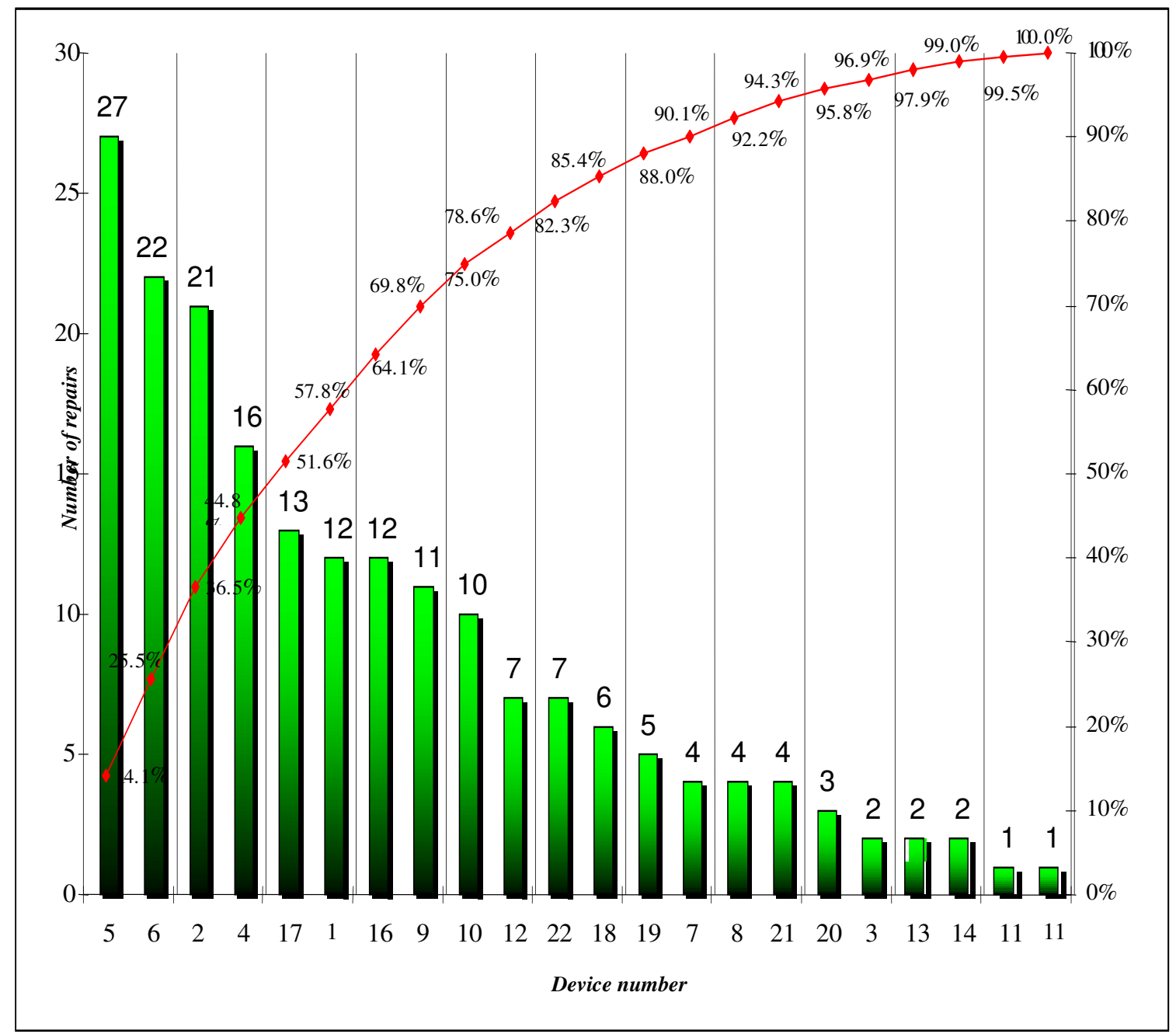

Fig. 1. Pareto - Lorenz diagram

Taking into account the percentage of these 9 machines, it can be concluded that a total of $45.5 \%$ of the machine types causes as much as $78.6 \%$ of failures. The remaining 12 machines cause $21.4 \%$ of repairs.

It follows that the first 9 machines should be analyzed in the first place.

The most worn-out machine on the washer is Drewboy 3.2 (Fig. 2). The Drewboy 3.2 type two-product suspension enrichment is used to work with suspended heavy magnetite liquid. Thanks to the high reliability of Drewboy 3.2 enrichment and the accuracy of the heavy liquid specific gravity stabilization system, the process of coal enrichment is characterized by high movement reliability and accuracy of enrichment.

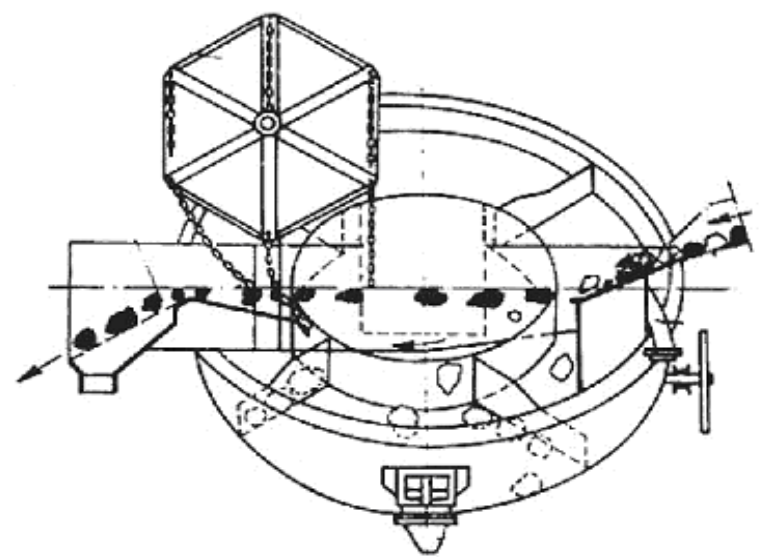

Fig. 2. Drewboy 3.2 Heavy liquid enrichment 
The enrichment unit consists of a work-box with an oblique bottom, on the side of which a vane wheel, inclined at an angle of $50^{\circ}$ from the vertical, is built in a suitable cover. The lower part of the wheel cover is directly connected to the inside of work-box. The lifting wheel's box structure protects the bottom of the wheel cover against friction caused by the waste slides on its surface. Raw coal is fed to the enrichment unit through a chute on the surface of the heavy liquid mirror (Krenicky, 2015). The concentrate is collected through an overflow threshold on an inclined chute, which is made of a slotted sieve. Under the sieve, a grab box is mounted, which flows down from the enricher along with the concentrate. The scraper built over the overflow threshold is equipped with loosely hanging chains, which act as scrapers of floating concentrate grains (Kuric et al., 2019). The heavy liquid is fed to the enricher through a feed spigot, while in the lowest point of work-box, there is a spigot allowing to empty the enricher from the heavy liquid. The waste collected by the wheel taken out of the enrichment is discharged outside via a chute, which is located at the highest point of wheel rotation. A worm gear drives the lifting wheel. In order to achieve the expected efficiency of this equipment, it is necessary to keep it in the first efficiency class at all times. In the group of machines causing the most repairs, there are up to 5 screens (Fig. 3), which is $50 \%$ of the most failure.

The elements of screens are exposed to constant friction and vibrations; thus, their parts wear out quite quickly.

Vibration screens (Fig. 3), single-deck PWP type are used for classification of coal and other loose materials in wet and dry processes as well as for desludging and dewatering etc.

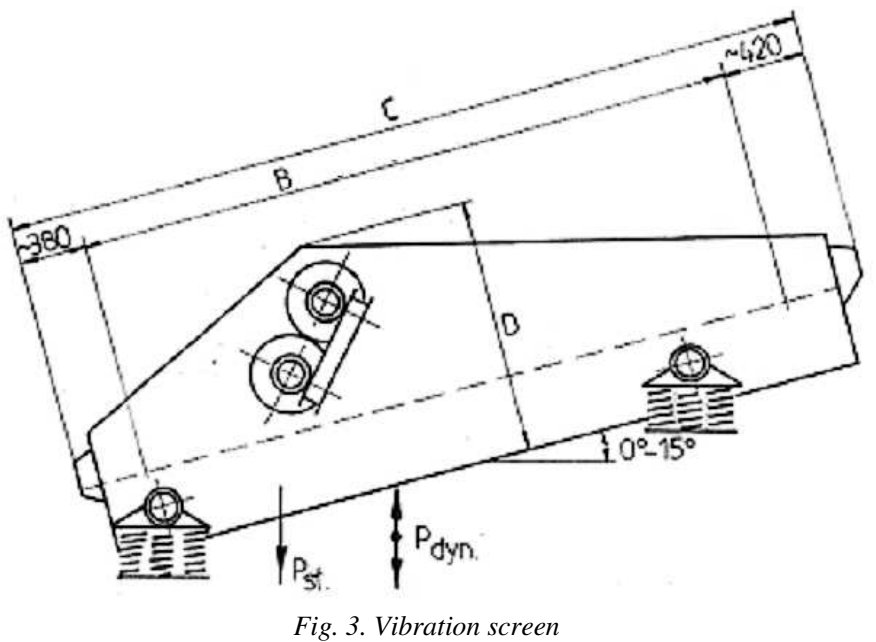

PWP1 type screens are used in coal processing plants for pre-classification processes in tandem arrangement with PWP1K type screens. PWP1K screens can be used for final classification and for dewatering of magnetite enrichment and flushing products (Table 3). Each screen has a modular design and consists of the following assemblies connected by screw joints:

- riddle,

- screen modules,

- 2 inertia drives,

- screener drive.

\begin{tabular}{|c|c|c|c|c|}
\hline \multirow{2}{*}{ Parameter } & \multicolumn{4}{|c|}{ Technical data } \\
\hline & PWP1 2.2×4.5 & PWP1 3.0×5.25 & PWP1K $1.5 \times 3.75$ & PWP1K $1.8 \times 5.25$ \\
\hline Efficiency in classification & $400 \mathrm{Mg} / \mathrm{h}$ & $720 \mathrm{Mg} / \mathrm{h}$ & $720 \mathrm{Mg} / \mathrm{h}$ & $240 \mathrm{Mg} / \mathrm{h}$ \\
\hline $\begin{array}{l}\text { Maximum grain size in the } \\
\text { feed }\end{array}$ & \multicolumn{4}{|c|}{ Up to $200 \mathrm{~mm}$} \\
\hline Sieve mesh size & \multicolumn{2}{|c|}{$\begin{array}{l}\text { for } 10 \mathrm{~mm}-80 \mathrm{~mm} \\
\text { classification } \\
\text { for } 0.25 \mathrm{~mm}-2.00 \mathrm{~mm} \text { dewatering }\end{array}$} & $12-80$ & $12-80$ \\
\hline
\end{tabular}

OŁ type pumps (Fig. 4) are also subject to frequent repairs. 


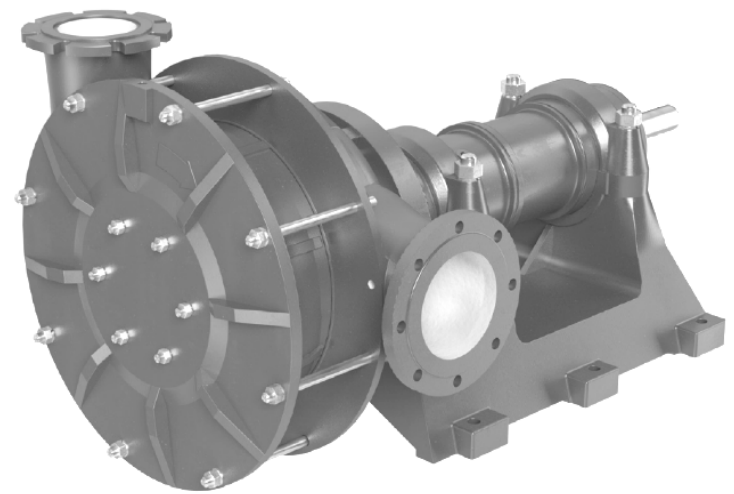

Fig. 4. OE pump

\section{Reliability and efficiency improvement}

The efficiency of production process depends largely on the failure-free operation of equipment at the mechanical coal processing stage, where commercial products are produced. Raw, unenriched product is not sold. In order to maintain the appropriate quality level of processed product, it is necessary to verify the correctness of equipment operation included in the coal enrichment process (Słabon, 2008). The enrichment process for coarse grains was selected for analysis (Vasko et al., 2020). After the analysis using the ParetoLorenzo diagram, information was obtained on the machines that generate the most failures.

Machines requiring frequent repairs:

- Enrichment Drewboy 3.2,

- Trapezoidal feeder,

- Screener,

- OŁ pumps.

The most common repairs on these machines are:

a) Enrichment Drewboy 3.2:

- Replacement of metal sheets

- Replacement of sieves

b) Trapezoidal feeder:

- Replacement of the crushing plates of excavated material

- Bearing replacement

c) Screeners:

- Beam replacement

d) OŁ pump

- Bearing replacement

- Pump replacement

- Rotor replacement.

The basic tasks of machine diagnostics are to detect emergency states and identify them (Turygin et al., 2018).

In order to improve the reliability of equipment, it is recommended to inspect the machines that have generated the most repairs more frequently (Semrád et al, 2020). It is important to avoid malfunctions during the operation process (Michalski \& Kunart, 2017). A portable infrared camera can be a helpful device during the inspection. It is ideal for maintenance and scheduled electrical and mechanical inspections (Draganová et al., 2020). As every mechanical component generates heat before it fails, it is easy to find damage (Blaschke, 1984; Tutak \& Brodny, 2019). The guarantee of high equipment durability and reliability during operation is the application of technical diagnostics, which correctly determines the technical condition of machines (Biały, 2017; Biały \& Fries, 2019; Brodny \& Tutak, 2018; Cacko \& Krenicky, 2014; Kuric et al., 2019). The measurements allow determining the technical condition of machines and equipment effectively, thus reducing emergency states, generations of service costs and avoiding losses in the company (Gajdzik \& Sitko, 2018; Urbaniak, 2004).

Computer visual and thermographic analysis of the tested objects is possible thanks to the software supplied with the camera (Słaboń, 2008; Szurgacz et al., 2019). The camera converts thermal radiation or invisible 
infrared into thermograms ready for analysis. LEDs illuminate the object under test, which enables efficient operation in an unlit environment (Górniak et al., 2018). This device performs non-contact temperature measurement and also has a digital photography function.

\section{Recommendations and methods of dealing with failures}

As a result of the failure analysis, the following measures are recommended:

\section{Carry out periodic inspections of the mechanical processing equipment}

Inspect and maintain the mechanical processing units according to the inspection and maintenance schedule and in accordance with the equipment's operating and technical documentation.

The person responsible for the preparation of inspection and maintenance schedules is the senior mechanical treatment supervisor responsible for maintenance management.

\section{Provide information on malfunctioning of mechanical processing equipment}

In accordance with the workplace instructions, the employee shall check the correct functioning of machines before start-up.

The persons responsible for providing information are:

Technical support employees

Traffic maintenance employees.

\section{Indicate the date of repair}

The Branch Foreman, on the basis of previously obtained information, shall indicate the date, manner and person responsible for the equipment repair

Decide when to carry out a major overhaul or replace the equipment with new ones. The overhaul plan is based on the technical and economic plan.

\section{Prepare the documentation for a major overhaul}

Prepare documentation for a major overhaul

The documentation should include specification of the scope of works, selection of the method for performance of works

Supervise the repair of mechanical processing equipment

Execution time: on an ongoing basis or in accordance with the scheduled repair date.

\section{Overhaul or replace the equipment with a new one}

Indicate the person authorized to carry out a major overhaul

This person is appointed by the department heads

If a defect is found during acceptance, action must be taken on an ongoing basis to rectify the identified defects.

\section{Conclusion}

The efficiency of production process depends largely on the trouble-free operation of machines at the mechanical stage of coal processing, where final products are produced. To maintain high efficiency and reliability, it is necessary to look at the correct operation of machines included in the coal enrichment process.

Technical diagnostics of equipment greatly impact the efficiency of detecting irregularitiesand defectsin the coal enrichment process. After the analysis, using the Pareto-Lorenz diagram, information was obtained on the machines that generate most failures.

It can be concluded that a total of $45.5 \%$ of the machine types causes as much as $78.6 \%$ of failures. The remaining 12 machines cause $21.4 \%$ of repairs. It follows that the first 9 machines should be analyzed in the first place.

The devices with the highest amount of downtime include heavy liquid enricher and screens.

Machines that needed frequent repairs include:

- Drewboy enrichment 3.2,

- trapezoidal feeder,

- various types of screens,

- two OŁ pumps,

- recuperator.

In order to improve the efficiency of these machines, more frequent inspections on the machines that generated the most failures are recommended. It is important to avoid failures during the equipment operation. 
A guarantee of high equipment durability and reliability in operation is the use of technical diagnostics, which correctly determines the technical condition of the machine.

It is recommended to carry out inspections, observations between main inspections using machines such as a vibration pen and thermal imaging camera to detect irregularities.

In order to avoid breakdowns caused by failures, the following solutions are proposed:

- use of rubber-coated steel sheets, which should reduce the level of wear and tear and the downtime associated with their replacement, as well as improve working conditions by reducing noise,

- replacement of perforated metal sheets with polyurethane (PU) screens, which will increase the time between screen changes and reduce the downtime associated with screen replacement and cleaning

- of the screen deck.

\section{References}

Akatov, N., Klačková, I., Mingaleva, Z., Galieva, G.,\& Shaidurova, N. (2019): Expert technology for risk management in the implementation of QRM in a high-tech industrial enterprise, Management Systems in Production Engineering, Vol. 27, Issue: 4, 250-254.

Biały, W. (2013). New devices used in determining and assessing mechanical characteristics of coal. $13^{\text {th }}$ SGEM GeoConference on Science and Technologies In Geology, Exploration and Mining, SGEM2013 Conference Proceedings, June 16-22, 2013, Vol. 1. 547-554.

Biały, W. (2014). Coal cutting force measurment systems, Exploration and Mining, SGEM2014 Conference Proceedings, June 17-26, 2014, Vol. III. 91-98.

Biały, W. (2017). Application of quality management tools for evaluating the failure frequency of cutter-loader and plough mining systems. Archives of Mining Sciences, Vol. 62, Issue 2, 2017. 243-252.

Biały, W., Wedzicha, J., \& Nordin, V. (2018). Measurement of Forces During the Extraction Process. Multidisciplinary Aspects of Production Engineering, Vol. 1, Issue 1. 117-128.

Biały, W., \& Fries, J. (2019). Computer Systems Supporting the Management of Machines/Equipment in Hard Coal Mines. Case Study. Management Systems in Production Engineering, Vol. 27 Issue 3/2019. 138143.

Biały, W. (2019). Equipment/machinery failure rate in hard coal mines. New Trends in Production Engineering, Monograph, Part 1. 353-363.

Bozek, P., Baranov, M., Prajova, V., Ivanova, T., Novokshonov, D., \& Korshunov, A. (2017). Constructing and calculating of multistage sucker rod string according to reduced stress. Acta Montanistica Slovaca, Vol. 22, Issue 2, 107-115.

Bozek, P., \& Turygin, Y. (2014). Measurement of the operating parameters and numerical analysis of the mechanical subsystem. Measurement Science Review. Vol. 14, No. 4, 198.

Brodny, J. (2012). Analysis of operation of new construction of the frictional joint with the resistance wedge. Archives of Mining Sciences, 57(1), 209-227.

Brodny, J., \& Tutak, M. (2016). Determination of the zone endangered by methane explosion in goaf with caving of operating longwalls. $16^{\text {th }}$ International Multidisciplinary Scientific SGEM Conference Proceedings, 1(2). 299-306.

Brodny, J., \& Szurgacz, D. (2017). An innovative system to test components of mining machinery control hydraulics. $17^{\text {th }}$ International Multidisciplinary Scientific GeoConference. Science and technologies in geology, exploration and mining, issue 13, Sofia: STEF92 Technology. 47-54.

Brodny, J., \& Tutak, M. (2018). Determination of the zone with a particularly high risk of endogenous fires in the goaves of a longwall with caving. Journal of Applied Fluid Mechanics, 1(3), 545-553.

Brodny, J., \& Tutak, M. (2019). Analyzing the utilization effectiveness of mining machines using independent data acquisition systems. A case study. Energies 12, 2505.

Bołoz, Ł., \& Midor, K. (2018). Process innovations in mining industry and effects of their implementation presented on example of longwall milling heads, Acta Montanistica Slovaca, 23(3), 282-292.

Blaschke, W., \& Nycz, R. (2003). Production problems of clean energetic hard coal. Scientific Journals Pol. Koszalińska, series Environmental Engineering, booklet 21, Koszalin, 248-252.

Blaschke, W., \& Nycz, R. (2007). Mechanical processing in the first stage of clean coal technology. Mineral Engineering 1/19, 224-232.

Cacko, P., \& Krenicky, T. (2014). Impact of lubrication interval to operating status of bearing.Applied Mechanics and Materials, 616, 151-158.

Gajdzik, B., \& Sitko, J. (2014). An analysis of the causes of complaints about steel sheets in metallurgical product quality management systems. Metalurgija53(1), 135-138.

Dodok, T., Cubonova, N.,\& Cisar, M. (2017), Utilization of strategies to generate and optimize machining sequences in CAD/CAM. 12th International Scientific Conference of Young Scientists on Sustainable, 
Modern and Safe Transport Location: High Tatras, Book Series: Procedia Engineering, Vol. 192, 113118.

Draganová, K., Semrád, Spodniak, M. and Cúttová, M. Innovative analysis of the physical-mechanical properties of airport conveyor belts. Transportation Research Procedia, Vol. 51 (2020).20-27

Elbakian, A., Sentyakov, B., Bozek, P., Kuric, I.,\& Sentyakov, K. (2018). Automated Separation of Basalt Fiber and Other Earth Resources by the Means of Acoustic Vibrations. Acta Montanistica Slovaca, Vol. 23, 271-281.

Górniak A., Midor, K., Kaźmierczak, J., \& Kaniak, W. (2018). Advantages and disadvantages of using methane from CNG in motor vehicles in polish engine. Measurement of weldings incompatibility in constructions. Multidisciplinary Aspects of Production Engineering, 1. 241-247.

Krenicky, T. (2015). Non-contact study of surfaces created using the AWJ technology. Manufacturing Technology 15(1), 61-64.

Kuric, I. (2011). New methods and trends in product development and planning. 1st International Conference on Quality and Innovation in Engineering and Management, 453-456, ISBN: 978-973-662-614-2

Kuric, I., Gorobchenko, O., Litikova, O., Gritsuk, I., Mateichyk, V., Bulgakov, M.,\& Klačková, I. (2019). Research of vehicle control informative functioning capacity, Materials Science and Engineering, Vol. 776, Scientific Conference on Machine Modelling and Simulations, 3-6 September, Liptovský Ján, Slovakia.

Kuric, I., Cisar, M., Tlach, V., Zajacko, I., Gal, T., \& Wiecek, D. (2019). Technical Diagnostics at the Department of Automation and Production Systems. In Intelligent Systems in Production Engineering and Maintenance, Advances in Intelligent Systems and Computing, Vol. 835, 474-484.

Lutyński, A., \& Osoba, M. (2009). Mechanical problems of hard coal processing in 2020 perspective, Nowy Przemysł, 244-250.

Michalski, K., \& Kunat, D. (2017). Development of a method for conducting failure analysis of injection moulding machines based on the FMEA method in "Manufacturing Engineering Support Systems. Quality, Safety, Environment”, edited by A. Kuboszek and E. Milewska, Vol. 6, Issue 7, P.A. Nova, Gliwice. 183-190.

Saga, M., Blatnicka, M., Blatnicky, M., Dizo, J. \& Gerlici J. (2020). Research of the Fatigue Life of Welded Joints of High Strength Steel S960 QL Created Using Laser and Electron Beams, Materials, Vol.13, Issue 11, Article No: 2539

Sapietová, M. Sága, I.\& Kuric E., (2018). Application of optimization algorithms for robot systems designing. International Journal of Advanced Robotic Systems, Vol. 15, Issue 1, 20182.

Semrád, K., Draganová, K., Koščák, P. and Čerňan. J. (2020). Statistical prediction models of impact damage of airport conveyorbelts. Transportation Research Procedia, Vol. 51 (2020). 11-19.

Słaboń, Ł. (2008). Thermodynamic analysis of the combustion process in the Isover polymerization chamber. Institute of Thermal Technology, Silesian University of Technology, 42-48, Gliwice.

Szurgacz, D., Sobik, L., \& Brodny, J. (2019). Integrated method of reducing the threat of endogenous fires in hard coal mines. E3S Web of Conferences, 105, 01013.

Turygin, Y., Bozek, P., Abramov, I., \&Nikitin, Y. (2018). Reliability determination and diagnostics of a mechatronic system. In Advances in Science and Technology Research Journal. Vol. 12, Issue 2, 274290.

Tutak, M., \& Brodny, J. (2019). Predicting methane concentration in longwall regions using artificial neural networks. International Journal Environmental Research Public Health 16, 1406; 1-22. DOI:10.3390/ijerph16081406.

Václav, S., Sivtsev, N. \& Senderská, K. (2017). Investigation of stress-strain state of a workpiece at gauge burnishing of its holes. In Advances in Science and Technology Research Journal. Vol. 11, iss. 3 (2017), pp.211-222.

Vasko, M., Saga, M., Majko, J., Vasko, A. \& Handrik M. (2020). Impact Toughness of FRTP Composites Produced by 3D Printing, Materials, Vol.13, Issue 24, Article No: 5654, DOI: 10.3390/ma13245654. 